\title{
IMPLEMENTASI ARDUINO NANO DAN REED SWITCH UNTUK PERMAINAN EDUKASI HAFALAN DOA ANAK USIA DINI
}

\author{
Vivianti $^{1}$, dan Dwi Ratnawati ${ }^{2}$ \\ ${ }^{1,2}$ Universitas Teknologi Yogyakarta \\ Email: vivianti@uty.ac.id
}

\begin{tabular}{l}
\hline Info Artikel \\
\hline SejarahArtikel: \\
Diserahkan 27 Juli 2019 \\
Direvisi 17 Oktober 2019 \\
Disetujui 18 November 2019 \\
\hline
\end{tabular}

\section{Keywords:}

ardunino nano, reed switch, educational game kit

\begin{abstract}
Abstrak
This study aims to create children's learning media in the form of educational games for dollhouses for daily prayer memorization and life skills education for early childhood.

The development method used in making this product is the method of research \& development $(R \& D)$. The stages of development used in this study consisted of needs analysis, identification of product specifications, product development, product validation, product revisions and trials. The subjects in this study amounted to 6 with the object of daily doll house prayer research. The data collection method used was a questionnaire filled out by trustees. The data analysis technique used in this research is descriptive analysis.

The final product is a doll house educational game kit that is integrated with Arduino nano and Reed switch. Products can produce daily prayer sounds and various sound effects that support children's competence in memorizing daily prayers and life skills education. Reed switches are placed in parts of the dollhouse that are set to produce sound. This educational game is presented in a package with Muslim dolls in which there are magnets. When the doll is about a Reed switch, the program on Arduino Nano will give a command to the DFPlayer mini to turn on the sound of prayer and sound effects in accordance with the role activities carried out by children.
\end{abstract}

\begin{abstract}
Abstrak
Penelitian ini bertujuan untuk membuat media belajar anak dalam bentuk permainan edukatif rumah boneka untuk hafalan doa sehari-hari dan pendidikan keterampilan hidup untuk anak usia dini.

Metode pengembangan yang digunakan dalam pembuatan produk ini yaitu metode riset \& pengembangan (R\&D). Tahapan pengembangan yang dipakai dalam penelitian ini terdiri dari analisis kebutuhan, identifikasi spesifikasi produk, pengembangan produk, validasi produk, revisi dan uji coba produk. Subjek pada penelitian ini berjumlah 6 dengan objek penelitian doll house doa sehari-hari. Metode pengumpulan data yang digunakan adalah kuesioner yang diisi oleh wali. Teknik analisis data yang digunakan dalam penelitian ini adalah analisis deskriptif.

Hasil akhir produk berupa kit permainan edukasi rumah boneka yang terintegrasi dengan Arduino nano dan Reed switch. Produk dapat menghasilkan suara doa sehari-hari dan berbagai sound effect yang mendukung peningkatan kompetensi anak dalam hafalan doa sehari-hari dan pendidikan keterampilan hidup. Reed switch diletakkan pada bagian-bagian rumah boneka yang disetting untuk menghasilkan suara. Permainan edukasi ini disajikan satu paket dengan boneka muslimah yang didalamnya terdapat magnet. Ketika boneka mengenai Reed switch maka program pada Arduino nano akan memberi perintah pada DFPlayer mini untuk menyalakan suara doa maupun sound effect sesuai dengan kegiatan peran yang dilakukan anak.
\end{abstract}




\section{Vivianti dan Dwi Ratnawati \\ IMPLEMENTASI ARDUINO NANO DAN REED SWITCH UNTUK PERMAINAN EDUKASI ... REFLEKSI EDUKATIKA : Jurnal Ilmiah Kependidikan 10 (1) Desember 2019. Hlm. 40-47}

\section{PENDAHULUAN}

Belajar merupakan salah satu proses yang dilakukan secara terus menerus untuk mendapatkan ilmu. Salah satu hal yang membantu dalam belajar adalah media. Media belajar merupakan salah satu bantuan yang digunakan untuk mempermudah dalam pembelajaran. Dunia anak adalah dunia bermain. Anak memperoleh pelajaran yang mengandung aspek perkembangan kognitif, sosial, emosi dan perkembangan fisik dengan bermain. Bermain merupakan sarana untuk menggali pengalaman belajar yang sangat berguna untuk anak dan menjadi sarana untuk mengembangkan kreativitas dan daya cipta, karena bermain adalah sumber pengalaman dan uji coba. Oleh karena itu dalam bermain dibutuhkan alat permainan yang mendidik yang disebut alat permainan edukatif (APE).

Permainan edukatif adalah permainan yang memiliki unsur mendidik dan memberi rangsangan atau respons positif terhadap indra penglihatan, pendengaran, afeksi, menulis, daya pikir kognitif, motorik, suara sertaspiritual dan sosial. Watak seseorang menentukan arah perjalannya hidupnya, untuk itu perlu ada keseimbangan indra yang akan mempengaruhi jasmani, nalar, watak dan karakter. Permainan dapat dikatakan edukatif selalu memiliki nilai guna, efektivitas, dan efisiensi yang mengarahkan proses mendidik secara positif, dan dapat dikontrol dan digunakan dengan tepat. Permainan yang tidak mempunyai latar belakang mendidikatau mengajak akan berdampak negatif terhadap anak. Permainan adalah sebagai media atau objek yang memberikan efek kesenangan dan mendukung terwujutnya motivasi positif pada siswa. Dengan kata lain, permainan sebagai upaya mempengaruhi psikologis siswa (Mujib dan Rahmawati, 2013)

Salah satu contoh bentuk kompetensi anak dalam pemenuhan kebutuhan jasmani dan rohani anak usia dini, khususnya anak muslim pada lembaga pendidikan anak usia dini adalah pembiasaan lifeskill dan hafalan doa sehari-hari. Lingkup perkembangan nilai-nilai agama dan moral untuk kelompok usia 4-6 tahun bahwa setiap siswa yang mengikuti pendidikan anak usia dini (PAUD) adalah (1) mengenal Tuhan melalui agama yang dianutnya; (2) menirukan gerakan beribadah; (3) mengucapkan doa sebelum dan/atau sesudah melakukan sesuatu; (4) mengenal perilaku baik/sopan dan buruk; (5) membiasakan diri berperilaku baik; serta (6) mengucapkan salam dan membalas salam (Kemendiknas, 2009).
Usia dini adalah usia dimana anak senang bermain. Bermain merupakan bentuk kreativitas mereka dalam keseharian. Cara yang tepat untuk memberi pelajaran atau mengajarkan hal baru pada anak usia dini adalah dengan belajar sambil bermain. Permainan merupakan salah satu media yang memudahkan anak dalam menyerap dan memahami hal baru dengan mudah. Pemanfaatan permainan dengan memasukkan unsur pendidikan memiliki banyak kelebihan (Haryani, et al., 2014). Lebih lanjut Santoso (2018) menjelaskan permainan memiliki sifat menghibur, terdapat unsur kompetisi, melibatkan partisipasi aktif peserta, luwes, mudah dibuat dan diperbanyak.

Salah satu bentuk permainan yang banyak disukai oleh anak adalah permainan peran menggunakan boneka. Penelitian ini bertujuan untuk membuat media ajaranak dalam bentuk permainan edukatif rumah boneka dan boneka muslim untuk hafalan doa sehari-hari dan pendidikan keterampilan hidup. Permainan ini dapat digunakan sebagai media bermain peran (role playing) anak.

Role playing (bermain peran) merupakan salah satu metode pembelajaran berdasarkan pengalaman yang menyenangkan, yakni suatu cara penguasaan bahan-bahan pelajaran melalui pengembangan imajinasi dan penghayatan siswa. Role playing (bermain peran) adalah salah satu proses belajar menggunakan metode simulasi (Mulyono, 2012). Permainan peran merupakan permainan yang mampu meningkatkan imajinasi anak, berinteraksi sosial dan mengekspresikan pengalamannya.

Permasalahan yang ditemukan pada penelitian ini relevan dengan penelitian sebelumnya yaitu penelitian yang dilakukan oleh Santoso, dan Pebriyani (2017) bahwa mempelajari doa harian merupakan salah satu kegiatan pembelajaran anak pada usia dini. Seperti telah diketahui ada berbagai macam buku pembelajaran mengenai doa harian, namun isi dari buku tersebut tidak bersifat interaktif dan menarik. Untuk membangkitkan motivasi minat belajar anak usia dini terhadap doa harian perlu dikembangkan suatu metode pembelajaran yang menarik dimanapun dan kapanpun mereka berada tanpa harus membawa buku tentang doa harian atau tidak harus menghabiskan banyak waktu berdiam diri di depan sebuah laptop dan personal komputer.

Penelitian lain dari Mulyani (2013) menyebutkan bahwa karakteristik boneka dalam kehidupan anak-anak adalah sebagai salah satu alat permainan manipulasi yang cocok untuk 


\section{Vivianti dan Dwi Ratnawati \\ IMPLEMENTASI ARDUINO NANO DAN REED SWITCH UNTUK PERMAINAN EDUKASI .. REFLEKSI EDUKATIKA : Jurnal Ilmiah Kependidikan 10 (1) Desember 2019. Hlm. 40-47}

menyalurkan perasaan dalam upaya untuk memecahkan masalah. Boneka sebagai media pembelajaran masih menjadi pilihan guru saat ini, hal ini disebabkan boneka menjadi alat peraga yang dianggap naturalitas dalam bercerita.

Berdasarkan beberapa penelitian tersebut dan hasil observasi lapangan, peneliti bermaksud untuk menciptakan sebuah produk mainan yang dapat digunakan sebagai media belajar oleh anak, khususnya dalam kompetensi hafalan doa sehari-hari dan pendidikan keterampilan hidup (life skill) menggunakan permainan peran. Produk berupa mainan berbentuk rumah boneka (doll house) berikut boneka dengan didukung rangkaian perangkat elektronika berupa Arduino nano dan Reed switch yang dapat menghasilkan output suara hafalan doa dan berbagai sound effect untuk mendramatisir permainan. Perbedaan hasil produk peneliti dibanding penelitian sebelumnya adalah penggunaan media yang mengkombinasikan antara permainan fisik dengan teknologi.

Thoules (2000) mendeskripsikan bahwa doa merupakan bentuk komunikasi dengan Tuhan sebagai satu upaya untukmembersihkan dan menghilangkan nilai-nilai kemusrikan dalam diri. Doa merupakan wujud komunikasi hamba kepada sang pencipta.). Sedangkan doa seharihari adalah doa yang diucapkan setiap hari terkait dengan kegiatan manusia setiap hari seperti doa sebelum dan bangun tidur, doa masuk dan keluar rumah, doa memakai pakaian dan lain sebagainya (Handiyanto, 2010).

Permainan edukasi yang dikembangkan dalam penelitian ini menggunakan berbagai macam komponen elektronika, antaralain Arduino nano, Reed switch, DFPlayer dan SD card.Arduino nano adalah Arduino dengan ukuran yang lebih kecil, jumlah pin digital sebanyak 14 pin, 8 pin analog, sedangkan arus DC input/output per pin sebesar $40 \mathrm{~mA}$. Tegangan masukkan yang dihasilkan Arduino nano sebesar 6-20 volt. Arduino yang digunakan dalam penelitian ini adalah Arduino nano ATmega 328 dengan Flash Memory $32 \mathrm{kB}$, SSRAM (Static Random Access Memory) $2 \mathrm{kB}$, EEPROM (Electrically Erasable Programmable Read Only Memory) 1 kB (Suwarti, dkk., 2017)

Standex Electronic (2008) menyebut Reed switch adalah saklar yang berbentuk satu-kontak kecil yang digunakan untuk kontrol beban tingkat rendah kurang dari $24 \mathrm{~V}$. Reed contact disegel dalam tube kaca dengan gas lembam untuk menjaga kehandalan kontak. Reed switch mempunyai kelebihan ukuran kecil, ringan, respon cepat, awet dan biaya rendah. Aplikasi umum dari reed switch berada di reed relay, sensor otomotif, sistem keamanan, robotika, mainan dan permainan. Prinsip dasar kerja sensor ini apabila bagian permukaan dari sensor berdekatan dengan medan magnet maka dua buah kontak plate tipis yang terdapat dibagian dalam sensor akan tertarik oleh medan magnet, sehingga kontak akan terhubung.

\section{METODE PENELITIAN}

Metode yang diguankan dalam penelitian ini adalah R\&D (Research and Development), yaitu suatu proses yang digunakan untuk pengembangan suatu produk, mengesahkan dan melihat dari produk tersebut. Tahapan pengembangan yang dipakai dalam penelitian ini terdiri dari analisis kebutuhan, identifikasi spesifikasi produk, pengembangan produk, validasi produk, revisi dan uji coba produk.

Memory card yang dipakai pada perancangan mainan edukasi ini adalah Micro SD (Secure Digital) dengan kapasitas 2 GB. Ada tiga macam cara berkomunikasi dengan SD card, yaitu One-bitSD mode, Four-bit SD mode, dan SPI (Serial Peripheral Interface) mode (Susanto, et al, 2013).

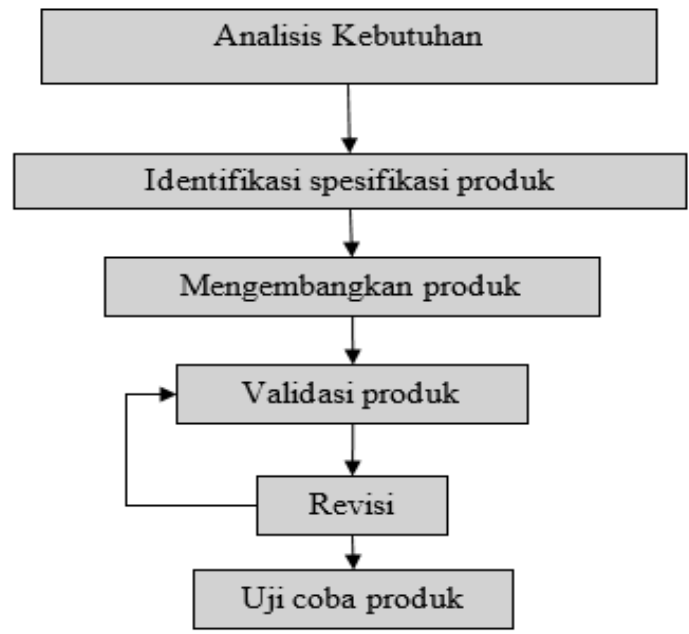

Gambar 1. Tahapan Pengembangan

Penelitian dilakukan pada tanggal 7 Juli 2019, bertempat di lingkungan tinggal peneliti dengan sasaran adalah anak PAUD/TK. Subjek pada penelitian ini berjumlah 6 dengan objek penelitian doll house doa sehari-hari. Metode pengumpulan data yang digunakan adalah kuesioner yang diisi oleh wali. Teknik analisis data yang digunakan dalam penelitian ini adalah analisis deskriptif. 


\section{Vivianti dan Dwi Ratnawati \\ IMPLEMENTASI ARDUINO NANO DAN REED SWITCH UNTUK PERMAINAN EDUKASI .. REFLEKSI EDUKATIKA : Jurnal Ilmiah Kependidikan 10 (1) Desember 2019. Hlm. 40-47}

Instrumen yang digunakan dalam penelitian ini terdiri atas 4 aspek yaitu aspek fisik, pemanfaatan, warna dan desain.

Tabel 1. Indikator Instrumen Penilaian

\begin{tabular}{lll}
\hline No & Indikator & Instrumen \\
\hline $\mathbf{1}$ & Fisik & Bahan yang digunakan \\
& & Ukuran \\
& & Keamanan \\
& & Keawetan \\
\hline $\mathbf{2}$ & Pemanfaatan & $\begin{array}{l}\text { Kebermanfaatan } \\
\text { Kepraktisan } \\
\end{array}$ \\
& & Petunjuk penggunaan \\
\hline $\mathbf{3}$ & Warna & Keserasian warna \\
& & Kesesuaian warna \\
\hline $\mathbf{4}$ & Desain & Komposisi desain \\
& & Kerapihan desain \\
& & Penyajian \\
\hline
\end{tabular}

\section{HASIL PENELITIAN DAN PEMBAHASAN}

Produk yang dikembangkan dalam penelitian ini adalah sebuah permainan edukasi dengan bentuk doll house atau rumah boneka dengan menggunakan Arduino nano dan Reed switch. Rumah boneka ini dibuat untuk memenuhi beberapa fungsi, diantaranya untuk membantu anak menghafal doa sehari-hari dan pendidikan keterampilan hidup (life skill) anak. Pembuatan doll house ini melalui beberapa tahapan, yaitu: analisis kebutuhan, Identifikasi spesifikasi produk, mengembangkan produk, validasi produk, revisi dan uji coba produk.

\section{Analisis Kebutuhan}

Tahap analisis kebutuhan mencakup studi eksploratif untuk mengkaji, menyelidiki dan mengumpulkan informasi. Langkah ini meliputi kegiatan-kegiatan seperti kajian pustaka, observasi di sekolah PAUD, serta identifikasi permasalahan yang dijumpai pada pembelajaran dan menghimpun data tentang faktor pendukung dan penghambat dalam pembelajaran. Selain itu, pada tahap ini juga dilakukan analisis kebutuhankebutuhan produk yang akan dikembangkan, diantaranya adalah kebutuhan alat dan bahan.

\section{Identifikasi Spesifikasi Produk}

Spesifikasi produk disesuaikan dengan kompetensi yang harus dikuasai anak. Desain fungsionalitas produk ditunjukkan pada gambar 2.

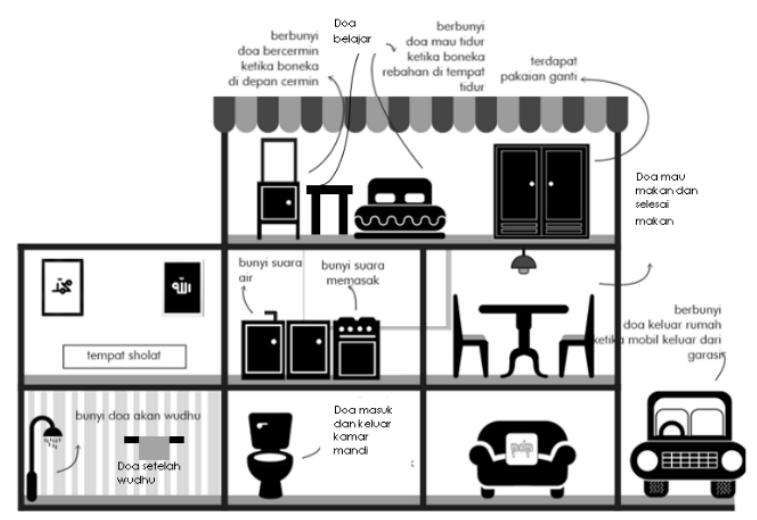

Gambar 2. Desain fungsionalitas produk

Produk dibuat untuk mendukung kompetensi anak, antara lain hafalandoa akan tidur dan bangun tidur, doa bercermin, doa akan belajar, doa akan makan dan selesai makan, doa akan berwudhu dan selesai berwudhu, doa masuk dan keluar kamar mandi dan doa keluar rumah.

\section{Mengembangkan Produk}

Produk mainan edukasi doll house ini disajikan satu paket dalam mainan berbentuk boneka muslimah untuk menarik minat anakanak. Boneka ini akan disisipi dengan magnet di dalamnya. Magnet diletakkan pada bagian kaki, tangan dan punggung boneka.

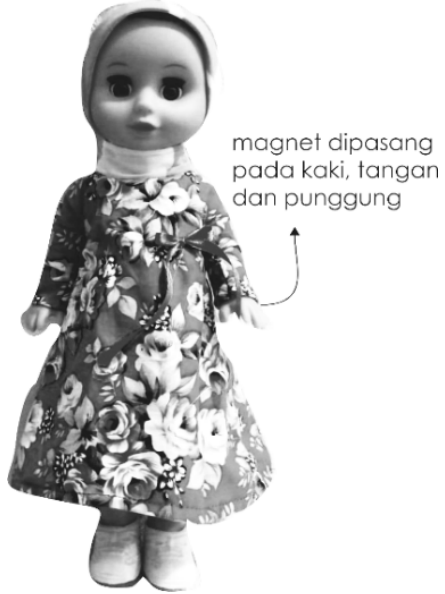

Gambar 3. Boneka muslimah

Prosedur kerja dari produk mainan ini adalah adalah pembacaan audio yang berupa doa sehari-hari dan berbagai sound efect untuk mendramatisir permainan. Sound ini akan berbunyi ketika boneka didekatkan bagian doll house yang telah dipasang reed switch. Proses ini ditunjukkan oleh diagram alir pada gambar 4. 
Vivianti dan Dwi Ratnawati

IMPLEMENTASI ARDUINO NANO DAN REED SWITCH UNTUK PERMAINAN EDUKASI ...

REFLEKSI EDUKATIKA : Jurnal Ilmiah Kependidikan 10 (1) Desember 2019. Hlm. 40-47

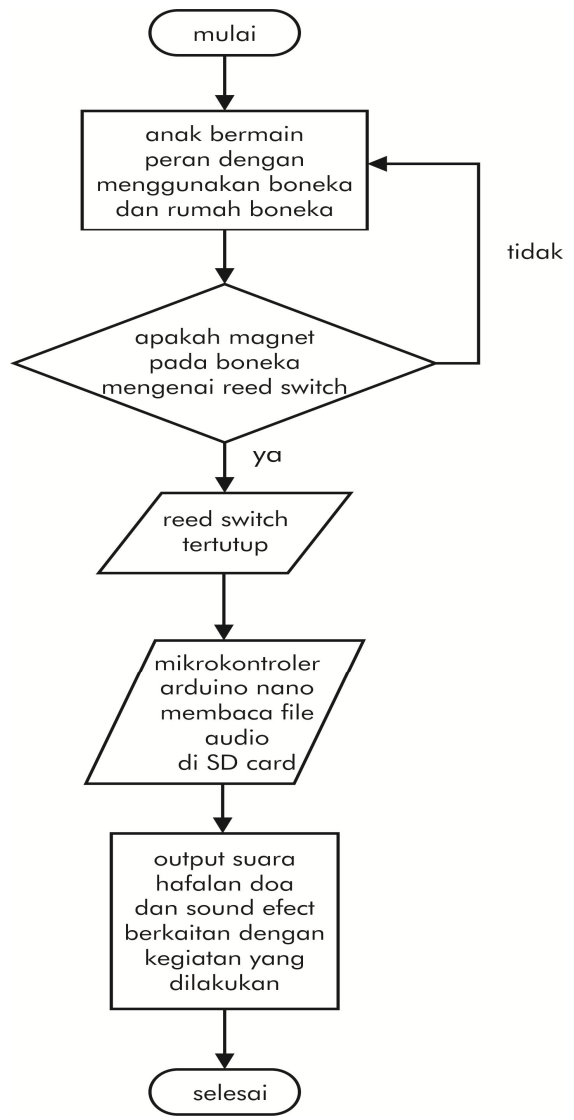

Gambar 4. Diagram alur kerja produk

Detail rangkaian elektronika pada produk ini diuraikan dalam penjelasan berikut:

\section{a. RangkaianPower Supply}

Rangkaian power supply yang digunakan pada permainan edukasi menggunakan IC regulator linier 7805. Rangkaian ini membutuhkan input $6-12 \mathrm{v}$ DC dan akan menghasilkan output 5v DV. Detail dari rangkaian power supply disajikan dalam gambar berikut.

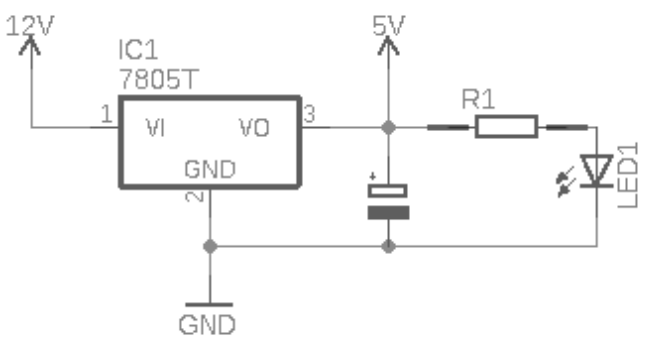

\section{Gambar 5. Rangkaian Power Supply}

\section{b. Rangkaian utama}

Rangkaian utama produk ini terdiri dari Arduino nano, DFPlayer mini, dan speaker. Arduino nano ini disupply tegangan 5v. Arduino nano dan DFPlayer mini berkomunikasi dengan metode serial, melalui pin TX (transmitter) dan RX (Receiver). Pin D2 - D13 dan A0 pada arduino nano terhubung dengan Reed switch yang disetting dengan input mode pull-up. Pada saat magnet pada boneka mengenai Reed switch, Arduino nano akan memberi perintah DFPlayer untuk menghidupkan audio dan sound effect yang outputnya akan terdengar dari speaker.
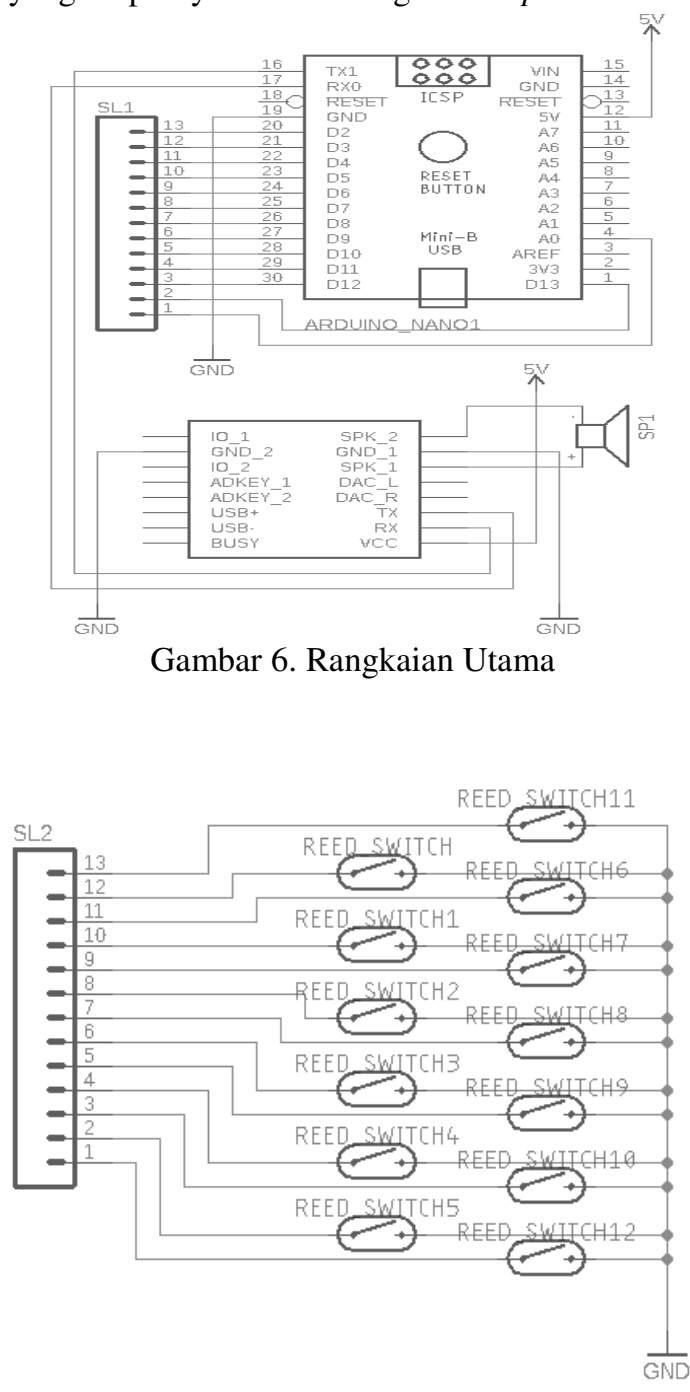

Gambar 7. Pemasangan Reed Switch

Ujung kabel yang sudah dipasang Reed switch ini diletakkan pada bagian-bagian dollhouse yang disetting untuk menghasilkan suara, yaitu: (1) tempat tidur untuk doa akan 


\section{Vivianti dan Dwi Ratnawati \\ IMPLEMENTASI ARDUINO NANO DAN REED SWITCH UNTUK PERMAINAN EDUKASI ... REFLEKSI EDUKATIKA : Jurnal Ilmiah Kependidikan 10 (1) Desember 2019. Hlm. 40-47}

tidur dan bangun tidur, (2) cermin untuk doa bercermin, (3) meja belajar untuk doa akan belajar, (4) kompor untuk sound effect suara memasak, (5) keran wastafel untuk sound effect suara air, (6) kursi makan untuk doa akan makan dan selesai makan, (7) keran untuk doa akan berwudhu, (8) gantungan handuk untuk doa selesai wudhu, (9) keset kamar mandi untuk doa masuk kamar mandi, (10) keset kamar mandi untuk doa keluar kamar mandi, (11) televisi untuk lagu islami, dan (12) garasi untuk doa keluar rumah.

Produk dibuat sedemikian rupa sehingga menarik minat anak. Sesuai dengan tujuannya untuk membuat media bermain peran yang bermanfaat bagi anak, produk juga dilengkapi dengan beberapa fasilitas untuk membantu anak dalam meningkatkan keterampilan hidup (life skill) seperti tesedianya pakaian muslim untuk membiasakan anak berpakaian yang baik, membiasakan anak mencuci piring setelah makan, beribadah (sholat) dengan rajin, dan lain sebagainya. Hasil jadi dari produk ditunjukkan pada gambar 8 .

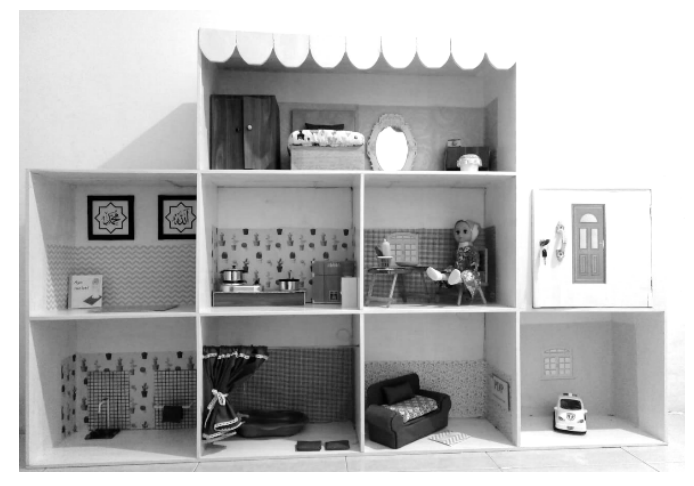

Gambar 8. Produk Jadi

\section{Validasi Produk}

Validasi produk dilakukan oleh ahli media dan ahli materi. Berdasarkan hasil validasi, terdapat beberapa revisi yang harus dilakukan yaitu perbaikan volume suara doa, dan perbaikan penempatan magnet pada tubuh boneka.

\section{Revisi}

Sesuai dengan masukan validator,maka dilakukan revisi berupa rekaman ulang serta perubahan posisi peletakan magnet pada tubuh boneka.

\section{Uji Coba Produk}

Uji coba lapangan skala kecil dilakukan dengan menggunakan kuesioner non tes yang terdiri dari 12 butir soal untuk 6 responden. Bobot tiap tanggapan responden yang dipilih atas tiap pernyataan, selanjutnya dilakukan perhitungan persentase skor. Rumus perhitungan persentase skor ditulis dengan rumus sebagai berikut (Arikunto, 2006).

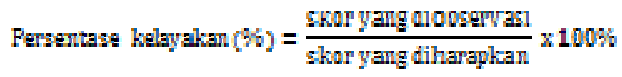

Setelah persentase didapatkan maka nilai tersebut dirubah dalam pernyataan predikat yang menunjuk pada pernyataan keadaaan, ukuran kualitas. Data yang terkumpul dianalisis dengan analisis deskriptif kuantitatif yang diungkapkan dalam distribusi skor dan presentase terhadap kategori skala penilaian yang telah ditentukan. Setelah penyajian dalam bentuk presentase, langkah selanjutnya mendeskripsikan dan mengambil kesimpulan tentang masing-masing indikator. Skor akhir yang diperoleh kemudian dikonversi lagi menjadi tingkat kelayakan media pembelajaran yang dihasilkan secara kualitatif dengan pedoman konversi pada tabel berikut (Arikunto, 2006).

Tabel 2 .Pedoman Konversi

\begin{tabular}{|c|c|c|}
\hline $\begin{array}{c}\text { Presentase } \\
\text { Pencapaian }\end{array}$ & $\begin{array}{c}\text { Skala } \\
\text { nilai }\end{array}$ & Interprestasi \\
\hline $76-100 \%$ & 4 & Sangat layak \\
\hline $56-75 \%$ & 3 & Layak \\
\hline $41-55 \%$ & 2 & Cukup \\
\hline $0-40 \%$ & 1 & $\begin{array}{c}\text { Kurang } \\
\text { layak }\end{array}$ \\
\hline
\end{tabular}

Berdasarkan hasil perhitungan persentase, 5 responden (83\% responden) menyatakan permainan edukasi ini sangat layak dan 1 responden (17\% responden) menyatakan permainan edukasi ini layak.

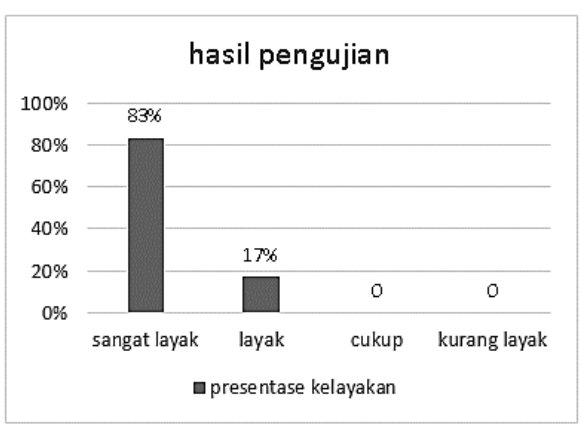

Gambar 9. Hasil Pengujian

Hasil penelitian ini memiliki persamaan dan perbadaan dengan riset Astini (2018), Bayu (2013), Elfiadi (2016), Najamuddin (2016), 


\section{Vivianti dan Dwi Ratnawati \\ IMPLEMENTASI ARDUINO NANO DAN REED SWITCH UNTUK PERMAINAN EDUKASI .. REFLEKSI EDUKATIKA : Jurnal Ilmiah Kependidikan 10 (1) Desember 2019. Hlm. 40-47}

Wiwik (2017), dan Wira (2018). Adapun persamaan nya yaitu pada obyek penelitian berupa permainan anak. Sedangkan perbedaannya pada fokus penelitian sehingga hasil risetnya pun berbeda.

\section{SIMPULAN}

Berdasarkan hasil penelitian, maka dapat disimpulkan: (1) penelitian pengembangan ini menghasilkan permainan edukasi rumah boneka yang terintegrasi dengan Arduino nano dan Reed switch. Produk dapat menghasilkan suara doa sehari-hari dan berbagai sound effect yang mendukung peningkatan kompetensi anak dalam hafalan doa sehari-hari dan pendidikan keterampilan hidup, (2) produk yang dikembangkan dalam penelitian ini layak untuk digunakan dan diaplikasikan pada anak usia dini dan dapat membantu anak dalam menghafal doa sehari-hari serta meningkatkan keterampilan hidup.

Saran bagi pengembangan selanjutnya, akan lebih baik apabila dapat bekerjasama dengan produsen mainan anak supaya kualitas produk yang dihasilkan lebih baik dan lebih menarik.

\section{DAFTAR PUSTAKA}

Arikunto, S. 2006. Prosedur Penelitian Suatu Pendekatan Praktik. Yogyakarta: Rineka Cipta.

Astini, Baik Nilawati., Nurhasanah, Nurhasanah., dan Nupus, Hayatun. 2018. Alat Permainan Edukatif Berbasis Lingkungan Untuk Pembelajaran Saintifik Tema Lingkungan Bagi Guru PAUD Korban Gempa. Jurnal Pendidikan Anak, 8 (1): 16

Elfiadi, E. 2016. Bermain dan Permainan Bagi Anak Usia Dini. Itqan, VII (1): 51-60.

Handiyanto, T. 2000. Studi Komparasi Kemampuan Menghafalkan Doa SehariHari antara Anak-anak di RA Al Hidayah Dharma Wanita Persatuan IAIN Walisongo dan Anak-anak di TK Al Hidayah IX Ngaliyan Semarang (Skripsi) IAIN Walisongo.

Haryani, C., Wadin, W., \& Sofino, S. 2014. Penerapan Metode Bermain dengan Media Playdough dalam Meningkatkan
Kemampuan Mengenal Konsep Bilangan dan Lambang Bilangan pada Anak Usia Dini (Disertasi Doktor). Bengkulu: Universitas Bengkulu.

Kemendiknas. 2009. Salinan Peraturan Menteri Pendidikan Nasional Republik Indonesia Nomor 58 Tahun 2009 Tentang Standar Pendidikan Anak Usia Dini.

Mujib, F. \& Rahmawati, N. 2013. Metode Permainan-Permainan Edukatif dalam Belajar Bahasa Arab. Yogyakarta: Diva Press.

Mulyani, S.A. 2013. Penggunaan Boneka Sebagai Media Simulasi Kreatif Di Sekolah Dasar. Jurnal Pemikiran dan Pengembangan SD, 1 (2).

Mulyono. 2012. Strategi Pembelajaran. Malang: UIN Maliki Press.

Najamuddin, A. 2016. Membangun Karakter Anak Lewat Permainan Tradisional Daerah Gorontalo. Tadbir : Jurnal Manajemen Pendidikan Islam 4 (1).

Nugraha, Bayu. 2013. Permainan Kreatif Untuk Anak Usia Dini. Jurnal Pendidikan Anak, 2 (1): 203-210.

Pertiwi, Wira. 2018. Peningkatan Kreativitas Melalui Bermain Tari Kreasi Berbasis Multimedia. Jurnal Pendidikan Anak, 7 (2): 106-121.

Pratiwi, Wiwik. 2017. Konsep Bermain Pada Anak Usia Dini. TADBIR : Jurnal Manajemen Pendidikan Islam, 5 (2): 106117.

Standex Electronics.1998. Reed Switch Data Book.

Santoso, B. \& Pebriyani, O. 2017. Aplikasi Pembelajaran Doa Harian Untuk Anak Usia Dini Berbasis Android. Jurnal Informatika Universitas Pamulang, 2 (4).

Santoso, S. 2018. Penerapan Konsep Edutainment dalam Pembelajaran di Pendidikan Anak Usia Dini (PAUD). Inopendas: 1 (1). 
IMPLEMENTASI ARDUINO NANO DAN REED SWITCH UNTUK PERMAINAN EDUKASI ... REFLEKSI EDUKATIKA : Jurnal Ilmiah Kependidikan 10 (1) Desember 2019. Hlm. 40-47

Susanto, H., Pramana, R., \& Mujahidin, M. 2013. Perancangan Sistem Telemetri Wireless untuk Mengukur Suhu dan Kelembaban Berbasis Arduino Uno R3 ATmega328p dan XBee Pro. Riau: Universitas Maritim Raja Ali.

Suwarti, et al. 2017. Pembuatan Monitoring Kecepatan Angin dan Arah Angin Menggunakan Mikrokontroler Arduino. Seminar Nasional Pendidikan, Sains dan
Teknologi Fakultas Matematika dan Ilmu Pengetahuan Alam Universitas Muhammadiyah Semarang.

Tedjasaputra Myeke. 2011. Bermain, Mainan dan Permainan untuk Pendidikan Anak Usia Dini. Jakarta: Grasindo

Thouless, R.H. 2000. Pengantar Psikologi Doa. Cet. Ketiga. Jakarta: Raja Grafindo Persada. 